IRA-International Journal of Management \& Social Sciences

ISSN 2455-2267; Vol.07, Issue 03 (2017)

Pg. no. $465-478$

Institute of Research Advances

http://research-advances.org/index.php/RAJMSS

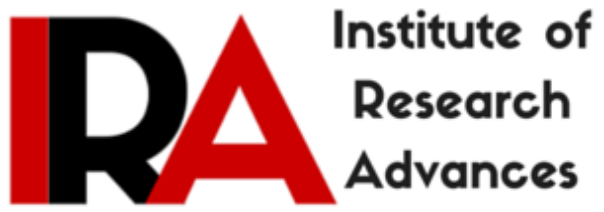

\title{
Employees' Perception on Performance Appraisal and Their Work Outcomes in Nepalese Service Sector
}

Gangaram Biswakarma $\mathrm{PhD}$

Assistant Professor, Central Department of Management, Tribhuvan University Kirtipur, Kathmandu, Nepal.

Type of Review: Peer Reviewed.

DOI: http://dx.doi.org/10.21013/jmss.v7.n3.p8

\section{How to cite this paper:}

Biswakarma, G. (2017). Employees' Perception on Performance Appraisal and Their Work Outcomes in Nepalese Service Sector. IRA-International Journal of Management \& Social Sciences (ISSN 2455-2267), 7(3), 465-478. doi:http://dx.doi.org/10.21013/jmss.v7.n3.p8

(C) Institute of Research Advances

\section{(cc) EY-NC}

This work is licensed under a Creative Commons Attribution-Non Commercial 4.0 International License subject to proper citation to the publication source of the work.

Disclaimer: The scholarly papers as reviewed and published by the Institute of Research Advances (IRA) are the views and opinions of their respective authors and are not the views or opinions of the IRA. The IRA disclaims of any harm or loss caused due to the published content to any party. 


\begin{abstract}
This paper examines the employees' perception on performance appraisal and their work outcomes in Nepalese service sector. The aim of this paper is to aid service sectors in Nepal to evaluate their existing performance appraisal systems, by identifying the perceived satisfaction of employees towards their current performance appraisal process. It can provide and promote excellent feedback towards their employees thus enhancing employees' work performance, affective commitment, employee engagement while reducing employee turnover intentions. This paper emphasized on one independent variable employees' perception of performance appraisal and four dependent variables work performance, affective commitment, employee engagement and turnover intention. The data are collected from the questionnaire and were analyzed and interpreted through the help of different statistical tools. The result highlighted that there is significant (positive) relationship of performance appraisal with work performance, affective commitment and employee engagement and a (negative) relationship between performance appraisal and turnover intention.
\end{abstract}

Keywords: Performance Appraisal, Work Performance, Affective Commitment, Employee Engagement and Turnover Intention.

\title{
INTRODUCTION
}

In this world of competition as organizations effort to remain competitive and sustainable, human resource professionals and strategic planners should collaborate strongly in designing strategies, which are more productive and useful (Ahmed et al, 2010). One of the most important and difficult part of managing the human resource is to identify the performers out of non-performers and create an environment in which the performers are rewarded and motivated to perform even better while the non-performers are identified (Biswakarma, 2016). Performance appraisal is one of the main functions of Human Resource Management. It is a vital tool to measure the frameworks set by any organization to its employees. An organization implements the performance appraisal system to allocate rewards for the employee, provide development advice as well as to obtain their perspectives, and justice perception about their jobs, department, managers, and organization. A good perception will create a positive working environment in the organization, while a negative perception will affect the company performance. And, these perceptions depend on the manager or supervisor's actions and behaviors toward the employee. Performance Appraisals are an important part of organizational life because they can serve a number of functions/purposes, including solving performance problems, setting goals, administering rewards and discipline, and dismissal (Ilgen, 1993). An organization is a set of relationships between different human resources with defined roles and functions to achieve certain goals. Therefore, it is necessary to correlate performance related goal setting and individual performance contracts to meet organizational objectives. Human resource is the most important factor in attaining such goals (Pandey, 1988).

This study was conducted with the aim to explore the relationship that exists between employee's perception of performance appraisal and their work outcomes, in the form of work performance, affective commitment, employee engagement and turnover intention. Taking this into account, the present study attempts to examine the perception of the employees of Nepalese Service Sector towards the various aspects of the current performance appraisal system and its impact on their work outcomes.

\section{RESEARCH OBJECTIVES}

- To examine the employee perception on existing performance appraisal system in Nepalese service sector.

- To examine the relationship between employee's perception of performance appraisal and work performance. 
- To examine the relationship between employee's perception of performance appraisal and affective commitment.

- To examine the relationship between employee's perception of performance appraisal and turnover intention.

- To examine the relationship between employee's perception of performance appraisal and employee engagement.

\section{RESEARCH HYPOTHESES}

The following four null hypotheses are formulated in this study:

$\mathrm{H}_{0} 1$ : There is no significant relationship between Perception of Performance Appraisal and Work Performance.

$\mathrm{H}_{0}$ 2: There is no significant relationship between Perception of Performance Appraisal and Affective Commitment.

$\mathrm{H}_{0} 3$ : There is no significant relationship between Perception of Performance Appraisal and Employee Engagement.

$\mathrm{H}_{0} 4$ : There is no significant relationship between Perception of Performance Appraisal and Turnover Intention.

\section{LITERATURE REVIEW}

\section{Performance Appraisal}

Performance Appraisal is the systematic evaluation of the individual with respect to his or her performance on the job and his or her potential for development. Khan (2013) opines that 'performance appraisal is a method of evaluating the behaviors of employees in the work spot, normally including both the quantitative and qualitative aspect of job performance.' Rao (2005) opines that 'performance appraisal is a method of evaluating the behavior of employees in work spot, normally including both the quantitative and qualitative aspects of job performance.' Appraisal is a key component of performance management of employees. When effective, the appraisal process reinforces the individual's sense of personal worth and assists in developing his/her aspirations (Maund, 2001).

\section{Work Performance}

Individual work performance is an extremely broad concept that is often oversimplified. The concept of work performance is however often vaguely defined and poorly understood (Barrick and Ryan, 2003; Murphy, 2002). Individual performance is of high relevance for organizations and individuals alike. Showing high performance and accomplishing task results in satisfaction, feeling of selfefficacy and mastery (Bandura, 1997 and Kanfer et al., 2005).

A heuristic framework of work performance consists of four broad and generic dimensions. The first dimension, task performance, refers to the proficiency with which the employee performs central job tasks. The second dimension, contextual performance, refers to employee's behaviors that support the organizational, social and psychological environment in which the central job task is performed. The third dimension, adaptive performance, refers to an employee's proficiency in adapting to the changes in work role or environment. The fourth dimension, counterproductive work behavior, refers to the behavior that is harmful for the well-being of the organization. In this instance, work performance can be defined as the accomplishment of assigned tasks (Suliman, 2001).

\section{Affective Organizational Commitment}

$\mathrm{AC}$ is defined as the employee's positive emotional attachment to the organization. Meyer and Allen pegged AC as the "desire" component of organizational commitment.(Allen and Meyer, 1991). This form of commitment is the most influential one because employees with high affective organizational commitment stay in an organization because they want to and not because they have to. Moreover, 
performance appraisal causes to increase employees' understanding of the sense of being valuable and know themselves as part of the organizational team that is the main understanding for being committed to the organization. Levy and Williams (2004) noted that PA activities have potential to increases employees' perception of being valued by the organization, apperception which is central to affective commitment.

\section{Turnover Intention}

The ratio of number of organization members who left during the period being considered divided by the average number of people in the organization during the period is turnover (Price, 1977). In most cases turnover is referred as entire process associated with filling a vacancy. Each time a position is vacated, both voluntarily and involuntarily, a new employee must be hired and trained; and this replacement cycle is known as turnover. It is an individual own estimated (subjective) probability that they are permanently leaving the organization at some point in the near future (Vandenberg and Nelson, 1999). Some authors suggest that perceptions about fairness in performance appraisal system hold a critical importance within organizations because it avoids negative outcomes such as employee turnover and also enhance positive outcomes of organizations such as commitment and satisfaction with the job (Selvarajan and Cloninger, 2009).

\section{Employee Engagement}

The International Survey Research (2003), formally defines employee engagement as a process by which an organization increases commitment and contribution of its employees to achieve superior business results. Engagement at work was conceptualized by (Kahn, 1990), as the harnessing of organizational members' selves to their work roles. In engagement, people employ and express themselves physically, cognitively, and emotionally during role performances. Kahn (1990), goes on to suggest that employees experience dimensions of personal engagement (or disengagement) during daily task performances.

Disengaged employees display incomplete role performances and task behaviors become effortless, automatic or robotic (Hochschild, 1983). Hochschild (1983), stated that unemployment of the self in one's role is considered as robotic or apathetic behavior. Employee engagement focuses on how the psychological experiences of work and work contexts shape the process of people presenting and absenting themselves during task performances. Kahn (1990), suggested that there are two major dimensions of engagement which include emotional and cognitive engagement. To be emotionally engaged is to form meaningful connections to others and to experience empathy and concern for others feelings. In contrast, being cognitively engaged refers to those who are acutely aware of their mission and role in the work environment.

\section{Relationship of Performance Appraisal and Work Performance}

Vignaswaran (2008), indicated that satisfaction with performance appraisal process positively influence employee's work performance. Further the relationship in between satisfaction with performance appraisal and work performance was fully mediated by intrinsic motivation. Klein and Snell (1994), noted that goal setting in performance appraisal process had a greater impact on attitudinal reactions for poor performers, probably because these employees needed goal setting to clarify what was needed in order to improve performance. Femi (2013), has examined the relationship that exists between Performance Appraisal and worker's performance and concluded that the adoption of the right performance appraisal technique in an organization was found to improve worker's performance and commitment.

\section{Relationship of Performance Appraisal and Affective Organizational Commitment}

Process in evaluating the performance of employees is one of the most important determinants of organizational justice (Greenberg, 1986). The majority of researchers have treated affective commitment as a dependent variable in their studies (Morrow,1983 in DeCotiis and Summers, 1987). Viewing commitment as an affective or emotional attachment to an organization is the most common approach in the literature to studying commitment (Mowday et al, 1982). Further review in the literatures indicates that fair practices in human resource management, particularly in terms of 
performance appraisal has a predictive role in the employees' attitude such as the organization's commitment (Jehad et al., 2011). Performance appraisal is viewed as an important mechanism for changing employees' attitude and behaviors such as affective commitment (Morrow, 2011).

\section{Relationship of Performance Appraisal and Turnover Intention}

Vignaswaran (2008), explores the relationship between performance appraisal satisfaction and employee outcomes that indicated that satisfaction with performance appraisal process negatively influence employees' turnover intention. Further the relationship in between satisfaction with performance appraisal and turnover intention are partially mediated by intrinsic motivation. There are several researches in the past which have indicated similar relationships. Arshad, Masood and Amin (2013) suggests that when employees perceive that there is high level of Performance Appraisal Politics in an organization then they view that their appraisal is not conducted wisely. As the result the Performance Appraisal satisfaction is low resulting in higher level of Turnover Intention.

\section{Relationship of performance Appraisal and Employee Engagement}

Nurse (2005), has discussed the impact of appraisal on employees and organizations. He specifically suggested that results of appraisal provide information to managers to take further steps about promotions and development of employees. On the contrary (Rao, 2005) suggests that weak areas of performance are identified through effective performance appraisal system. In this way, managers can take decisions regarding training of employees to improve those weak areas.

An organization's capacity to manage employee engagement is closely related to its ability to achieve high performance levels and superior business results. According to Hewitt (2012), enhancing employee engagement creates a 'win-win' situation. Employees are happier and more productive and this ultimately leads to a positive impact on their performance and business results. Greenberg (2004) observes that employee engagement is critical to any organization that seeks not only to retain valued employees, but also to increase its levels of performance. The more highly engaged the employees are, the more likely is to have a strongly customer-focused organization.

\section{Conceptual framework for this study}

The conceptual model illustrated in figure no. 1 below explains the framework of the research process used in this study.

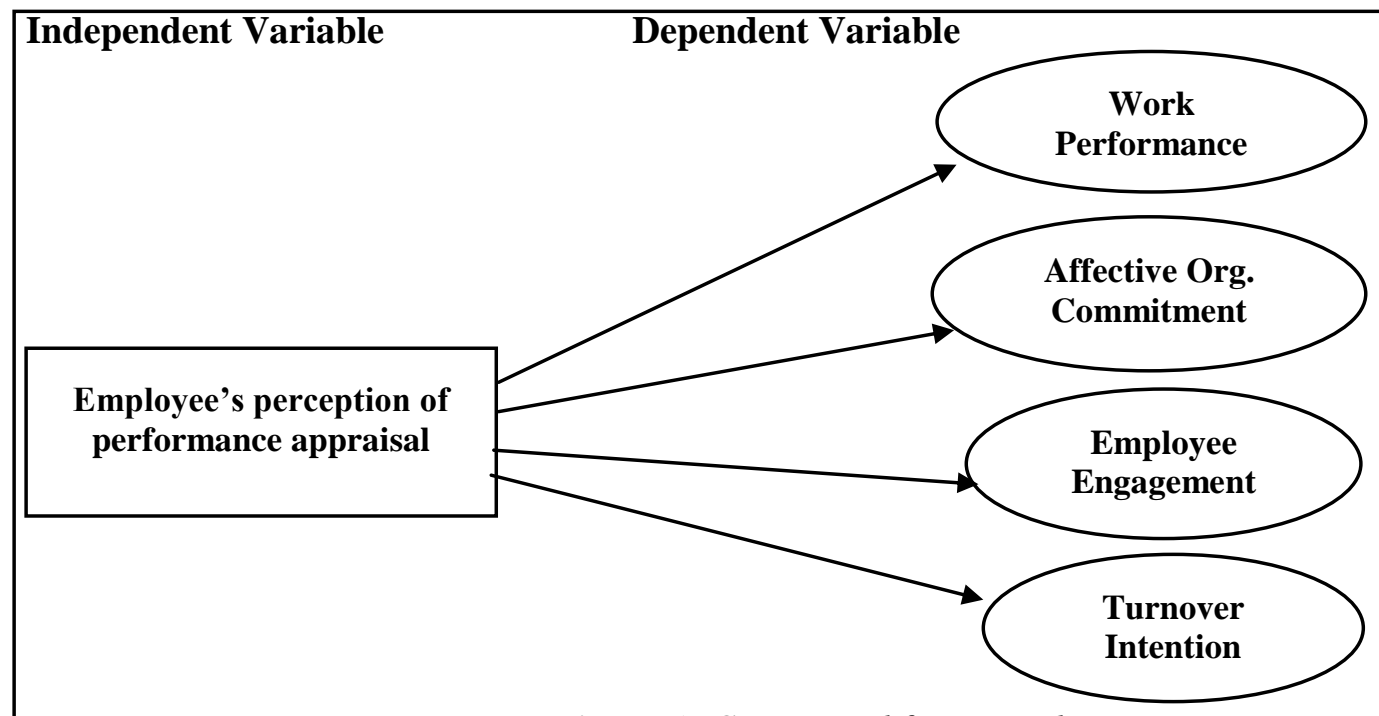

Figure 1: Conceptual framework 


\section{RESEARCH METHODOLOGY}

\section{Research design}

A descriptive as well as explanatory research was carried out for the purpose of this research. The research is descriptive, as it describes data and characteristics about the population being studied, without any form of manipulation and is explanatory, since it has been conducted to identify the nature of cause-and-effect relationships among the dependent and independent variables. In this research, the employees' work outcomes are measured in the form of Work Performance, Affective Commitment, Employee Engagement and Turnover Intention.

\section{Population and sample}

This study obtained a sample of 100 employees from various service organizations in Kathmandu Valley. Convenience sampling technique has been adopted. Those respondents who were easy to reach and collect the required information were considered for the study. The service organization includes- banks, hotels, airlines, hospitals, IT companies, consultancy firms within Kathmandu valley.

\section{Data Collection}

Questionnaires were handed out through delivery and collection method. Responses on the questionnaire were received within a period of 30 days. Out of the 100 questionnaires distributed, only 98 valid responses were collected through online questionnaire and personal visit. Hence, the response rate was 98 percent. Table 1 shows the type of the organization as sample for this study.

Table 1: Type of Service Organization

\begin{tabular}{|c|c|c|c|}
\hline Sl. No & Type of Service Organization & N & Percent \\
\hline 1 & Bank & 25 & 25.5 \\
\hline 2 & Hotel & 10 & 10.2 \\
\hline 3 & Hospital & 20 & 20.4 \\
\hline 4 & IT Company & 13 & 13.26 \\
\hline 5 & Consultancy Firm & 20 & 20.4 \\
\hline 6 & Airlines & 10 & 10.2 \\
\hline Total & & $\mathbf{9 8}$ & $\mathbf{1 0 0}$ \\
\hline
\end{tabular}

\section{Instrumentation}

Completion of the survey instruments provided the data to measure the independent variable 'Employee's perception of performance appraisal' and the dependent variable 'Employee's Work outcomes', i.e., Employee's work performance, Affective Commitment, Employee's Engagement and Employee's Turnover Intention. The subsequent employee's work outcomes attitude is measured in the form of Employee's work performance, Affective commitment, Employee's Engagement and Employee's Turnover Intention.

Employees' perception of performance appraisal: A total of 6 items were adapted from Vignaswaran (2005) and designed to measure the perception of the employee towards performance appraisal.

Affective commitment: A total of 6 items were adopted from Allen and Meyer (1990) from its original 8 items. All these items are deals with the affective commitment of employees.

Turnover intention: A total of 5 items were designed to measure the employees turnover intention. Among the 5 items were adapted from Vignaswaran (2005).

Employee engagement: The construct of Employee Engagement had three variables or dimensions of Vigor, Absorption and Dedication with nine (9) questionnaire items in original conceptualization of engagement given by Schaufeli et al. (2002). The 7 items were adapted for this construct in this study. 
Work performance: A total of 4 items were adopted from Vignaswaran (2005) and Gallato (2012), regarding with the overall work performance of employees of the organization understudy.

Out of 28 questionnaire items (alpha value 0.642), 6 items were developed to measure employee's perception of performance appraisal (alpha value 0.826), 4 items were developed to measure work performance (alpha value 0.744), 6 items were developed to measure affective commitment (alpha value 0.879), 5 items were developed to measure turnover intention (alpha value 0.877) and 7 items were developed to measure employee engagement (alpha value 0.851 ). Responses were reported on a 6 point Likert scale ranging from 1 (strongly disagree) to 6(strongly agree).

\section{Analysis Tools}

The study is based on various statistical tests and analyses. For this purpose, Statistical Package for Social Science (SPSS) software and Microsoft Excel was used to analyze and interpret the quantitative data. The first order exploratory factor was employed at the first stage of the data analysis procedure. Descriptive statistics was used for the calculation of mean and standard deviation based on the respondent profile. Correlation analysis, regression analysis was employed to test hypotheses.

\section{Exploratory Factor Analysis}

The study framework with the dimensions of Performance Appraisal, Work Performance, Affective Commitment, Employee Engagement and Turnover Intention. These dimensions were measured in 28 manifest items. The factor analysis with Principal Component Analysis, component rotated with Varimax with Kaiser Normalization, gives manifest 28 items into 5 (five) latent factors. The manifest items were loaded in their own respective factors. Test for sampling adequacy (KMO) and the Bartlett's test of sphericity is presented in table 2. The KMO statistics was 0.819 , which suggests that a factor analysis can be performed with a data set of the number of observations and the variables. Likewise, the Bartlett's test of sphericity suggests that, with the overall statistical significance of the correlations among the observed variables, we can perform factor analysis. The Chi-square value $(1734.421,378)$ is statistically significant at $(\mathrm{p}<0.01)$. The extracted communalities are all less that the initial value. Table 2, summarizes the communalities for all the variables used in the analysis.

The total variance explained by the different factors shows all the factors extractable from the analysis along with their eigenvalues $(8.927,3.799,2.255,1.755$, and 1.399 for respective 5 factors). The total variance is explained by the five factors, with cumulative variance of $68.749 \%$. Similarly, the factor loadings after rotation using a significant factor criterion were within the value of 0.5 . Detail EFA is presented at Table 3 with the factor loading, communalities, eigenvalues, and percentage of variance of each variable loaded strongly on five factors. Furthermore, the descriptive and inferential analysis is based on these classifications.

Table 2 : KMO and Bartlett's Test

\begin{tabular}{|l|l|r|}
\hline Kaiser-Meyer-Olkin Measure of Sampling Adequacy. & .819 \\
\hline Bartlett's Test of Sphericity & Approx. Chi-Square & 1734.421 \\
\cline { 2 - 3 } & df & 378 \\
\cline { 2 - 3 } & Sig. & .001 \\
\hline
\end{tabular}


Table 3 : Factor Analysis (Rotated component matrix)

\begin{tabular}{|c|c|c|c|c|c|c|c|c|c|c|}
\hline \multirow{2}{*}{$\begin{array}{l}\text { Sl. } \\
\text { No }\end{array}$} & \multirow{2}{*}{ Code } & \multicolumn{5}{|c|}{ Component } & \multirow{2}{*}{ Com } & \multirow{2}{*}{ EV } & \multirow{2}{*}{ PV } & \multirow{2}{*}{$\mathbf{C A}$} \\
\hline & & 1 & 2 & 3 & 4 & 5 & & & & \\
\hline 1 & OC1 & 0.595 & & & & & .661 & \multirow{6}{*}{8.927} & \multirow{6}{*}{31.882} & \multirow{6}{*}{0.879} \\
\hline 2 & $\mathrm{OC} 2$ & 0.534 & & & & & .755 & & & \\
\hline 3 & OC3 & 0.806 & & & & & .722 & & & \\
\hline 4 & OC4 & 0.813 & & & & & .697 & & & \\
\hline 5 & OC5 & 0.841 & & & & & .669 & & & \\
\hline 6 & OC6 & 0.675 & & & & & .557 & & & \\
\hline 7 & TI1 & & 0.600 & & & & .736 & \multirow{5}{*}{3.799} & \multirow{5}{*}{13.569} & \multirow{5}{*}{0.877} \\
\hline 8 & TI2 & & 0.791 & & & & .481 & & & \\
\hline 9 & TI3 & & 0.818 & & & & .756 & & & \\
\hline 10 & TI4 & & 0.908 & & & & .762 & & & \\
\hline 11 & TI5 & & 0.886 & & & & .768 & & & \\
\hline 12 & PA1 & & & 0.776 & & & .785 & \multirow{6}{*}{2.255} & \multirow{6}{*}{8.055} & \multirow{6}{*}{0.826} \\
\hline 13 & PA2 & & & 0.775 & & & .572 & & & \\
\hline 14 & PA3 & & & 0.576 & & & .634 & & & \\
\hline 15 & PA4 & & & 0.784 & & & .664 & & & \\
\hline 16 & PA5 & & & 0.657 & & & .779 & & & \\
\hline 17 & PA6 & & & 0.596 & & & .799 & & & \\
\hline 18 & WP1 & & & & 0.513 & & .511 & \multirow{4}{*}{1.755} & \multirow{4}{*}{6.268} & \multirow{4}{*}{0.744} \\
\hline 19 & WP2 & & & & 0.780 & & .784 & & & \\
\hline 20 & WP3 & & & & 0.673 & & .576 & & & \\
\hline 21 & WP4 & & & & 0.618 & & .646 & & & \\
\hline 22 & EE1 & & & & & 0.653 & .610 & \multirow{7}{*}{1.399} & \multirow{7}{*}{4.996} & \multirow{7}{*}{0.851} \\
\hline 23 & EE2 & & & & & 0.604 & .757 & & & \\
\hline 24 & EE3 & & & & & 0.518 & .450 & & & \\
\hline 25 & EE4 & & & & & 0.622 & .716 & & & \\
\hline 26 & EE5 & & & & & 0.692 & .736 & & & \\
\hline 27 & EE6 & & & & & 0.504 & .857 & & & \\
\hline 28 & EE7 & & & & & 0.545 & .808 & & & \\
\hline
\end{tabular}

Extraction Method: Principal Component Analysis. Rotation Method: Varimax with Kaiser Normalization. Rotation converged in 9 iterations.

Com=Communalities; $E V=$ Eigenvalues; $P V=$ Percentage of Variance; $C A=C r o n b a c h$ 's Alpha

\section{Results}

\section{Respondent's Demographic Profile}

The respondent's demographic profile is presented in table 4, which includes information on gender, marital status, age-group, educational qualification, income level, work experience, types of organization of the respondents. The percentage of male respondents was $61.2 \%$ and that of female respondent was $38.8 \%$. Similarly, the age group of the respondents of below 20 years consists of $8.2 \%, 20-30$ years was $87.8 \%, 30-40$ years was $3.1 \%$ and $40-50$ years was $1.0 \%$. Likewise, out of 
total respondents surveyed, 11 were married i.e. $11.2 \%$ and 87 were unmarried i.e. $88.8 \%$. Out of total respondents, $15.3 \%$ respondents having Intermediate Degree, $48.0 \%$ having Bachelor's Degree and $36.7 \%$ were having Master's degree and above. Likewise, it has been found that 54.1 percent of the respondents earned lower than Rs. 20,000 and 23.5 percent of respondents earned between Rs. 20,000 to Rs. 40,000. Similarly, respondents with income level Rs. 40,000 to Rs. 60,000 were represented by 13.3 percent of total respondents and respondents with income level more than Rs. 60,000 were represented by 9.2 percent of total respondents. The distribution based on work experience shows that 49.0 percent of total respondents have experience of less than 1 year, 22.4 percent respondents have experience of 1-2 years, 16.3 percent respondents have experience of 2 to 3 years, 7.1 percent of respondents have experience of 3-4 years and 5.1 percent of respondents have experience of 4 years and above.

Table 4: Demographic Profile of Respondents

\begin{tabular}{|c|c|c|c|c|c|c|c|c|c|}
\hline Sl. No & Attributes & $\begin{array}{c}\text { Sub- } \\
\text { Attributes }\end{array}$ & No. & $\%$ & Sl. No & Attributes & $\begin{array}{c}\text { Sub- } \\
\text { Attributes }\end{array}$ & No. & $\%$ \\
\hline \multirow[t]{2}{*}{1} & \multirow[t]{2}{*}{ Gender } & Male & 60 & 61.2 & \multirow[t]{2}{*}{2} & \multirow{2}{*}{$\begin{array}{l}\text { Marital } \\
\text { Status }\end{array}$} & Married & 11 & 11.2 \\
\hline & & Female & 38 & 38.8 & & & Unmarried & 87 & 88.8 \\
\hline \multirow[t]{5}{*}{3} & \multirow[t]{5}{*}{ Age group } & Below 20 & 8 & 8.2 & \multirow[t]{5}{*}{4} & \multirow[t]{5}{*}{$\begin{array}{l}\text { Work } \\
\text { Experience }\end{array}$} & $\begin{array}{l}\text { Less than } \\
1 \text { year }\end{array}$ & 48 & 49.0 \\
\hline & & $20-30$ & 86 & 87.8 & & & 1-2 years & 22 & 22.4 \\
\hline & & $30-40$ & 3 & 3.1 & & & $2-3$ years & 16 & 16.3 \\
\hline & & & & & & & 3-4 years & 7 & 7.1 \\
\hline & & $40-50$ & 1 & 1.0 & & & $\begin{array}{l}4 \text { years \& } \\
\text { above }\end{array}$ & 5 & 5.1 \\
\hline \multirow[t]{4}{*}{5} & \multirow[t]{4}{*}{$\begin{array}{l}\text { Education } \\
\text { Level }\end{array}$} & Intermediate & 15 & 15.3 & \multirow[t]{4}{*}{6} & \multirow[t]{4}{*}{$\begin{array}{l}\text { Income } \\
\text { Level }\end{array}$} & $\begin{array}{l}\text { Below Rs. } \\
20,000\end{array}$ & 53 & 54.1 \\
\hline & & Bachelor & 47 & 48.0 & & & $\begin{array}{l}\text { Rs. } \\
20,000- \\
40,000\end{array}$ & 23 & 23.5 \\
\hline & & $\begin{array}{l}\text { Masters or } \\
\text { above }\end{array}$ & 36 & 36.7 & & & $\begin{array}{l}\text { Rs. } \\
40,000- \\
60,000\end{array}$ & 13 & 13.3 \\
\hline & & & & & & & $\begin{array}{l}\text { Rs. } 60,000 \\
\& \text { above }\end{array}$ & 9 & 9.2 \\
\hline
\end{tabular}

\section{Status of Perception on Performance Appraisal and Employees' Work Outcomes}

The overall descriptive findings indicate a moderate level of perception on performance appraisal in the Nepalese service sector organizations. This can be visualized with the mean values of all the variables determining the perception on performance appraisal are greater than 4 , stating a greater inclination towards agreeableness. The perception of performance appraisal is at agreeableness (moderate) with mean value of $4.5(S D=0.805)$. Likewise, Work Performance mean value of 4.67 $(S D=.755)$ which indicates the performance of the employees is at moderate level of performance. Affective Commitment has a mean value of $4.09(S D=.985)$ which indicates slightly agreeableness of the respondents, that indicates a moderate level of affective commitment. In similar manner, Employee Engagement has a mean value of $4.34(S D=.829)$ indicating a slightly agreeableness, that is moderate engagement. Turnover Intention has a mean value of $3.92(S D=1.29)$ indicates a slightly agreeableness. 
Table 5: Descriptive Analysis of the Variables

\begin{tabular}{|c|c|c|c|}
\hline SI. No & Variables & Mean & SD \\
\hline 1 & Performance Appraisal & 4.50 & .805 \\
\hline 2 & Work Performance & 4.67 & .755 \\
\hline 3 & Affective Commitment & 4.09 & .985 \\
\hline 4 & Employee Engagement & 4.34 & .829 \\
\hline 5 & Turnover Intention & 3.92 & 1.29 \\
\hline
\end{tabular}

\section{Relationship between Perception on Performance Appraisal and Employees' Work Outcomes}

The relationship of Perception on Performance Appraisal and Work Performance, Affective Commitment, Employee Engagement and Turnover Intention is presented in table 6. The Pearson Correlation coefficient between the Perception of Performance Appraisal and Work Performance is 0.452 , which implies that the two variables are positively correlated. The positive coefficient of correlation is 0.452 at $1 \%$ significant level where p-value is less than alpha i.e. $0.001<0.01$.

Similarly, the Pearson Correlation coefficient between the Perception on Performance Appraisal and Affective Commitment is 0.523 , which implies that the two variables are positively correlated. The positive coefficient of correlation is 0.523 at $1 \%$ significant level where p-value is less than alpha i.e. $0.001<0.01$.

The Pearson Correlation coefficient between the Perception on Performance Appraisal and Employee Engagement is 0.589 , which implies that the two variables are highly positively correlated. The positive coefficient of correlation is 0.589 at $1 \%$ significant level where p-value is less than alpha i.e. $0.001<0.01$.

Likewise, the Pearson Correlation analysis shows that there is no relationship between the Perception of Performance Appraisal and Turnover Intention, the value of $r=(-) 0.119$ and $p>0.05$. Therefore, there is no relationship between Perception of Performance Appraisal and Turnover Intention.

Table 6: Correlation Analysis of the Variables

\begin{tabular}{|c|r|r|}
\hline \multicolumn{2}{|c|}{$\begin{array}{c}\text { Dependent Variables } \\
\text { Work Performance }\end{array}$} & \multicolumn{2}{c|}{$\begin{array}{c}\text { Perception on Performance } \\
\text { Appraisal }\end{array}$} \\
\cline { 2 - 4 } & $\mathrm{p}$ & $.452^{* *}$ \\
\cline { 2 - 4 } & $\mathrm{N}$ & .001 \\
\hline Affective Commitment & $\mathrm{r}$ & 98 \\
\cline { 2 - 4 } & $\mathrm{p}$ & $.523^{* *}$ \\
\cline { 2 - 4 } & $\mathrm{N}$ & .001 \\
\hline Employee Engagement & $\mathrm{r}$ & 98 \\
\cline { 2 - 4 } & $\mathrm{p}$ & $.589^{* *}$ \\
\cline { 2 - 4 } & $\mathrm{N}$ & 901 \\
\hline Turnover Intention & $\mathrm{r}$ & $-.119^{* *}$ \\
\cline { 2 - 4 } & $\mathrm{p}$ & .245 \\
\cline { 2 - 4 } & $\mathrm{N}$ & 98 \\
\hline
\end{tabular}




\section{Hypotheses testing result}

$H_{0}$ 1: There is no significant relationship between Perception on Performance Appraisal and Work Performance.

The correlation result indicates that there is a positive relationship between the Perception on Performance Appraisal and work Performance at $1 \%$ significant level $(\mathrm{p}<0.01)$. Thus, null hypotheses (Ho1) is rejected.

\section{$\mathrm{H}_{0}$ 2: There is no significant relationship between Perception on Performance Appraisal and} Affective Commitment.

The correlation result indicates that there is a positive relationship between the Perception on Performance Appraisal and Affective Commitment at $1 \%$ significant level $(\mathrm{p}<0.01)$. Thus, null hypotheses (Ho2) is rejected.

$\mathrm{H}_{0}$ 3: There is no significant relationship between Perception on Performance Appraisal and Employee Engagement.

The correlation result indicates that there is a positive relationship between the Perception on Performance Appraisal and Employee Engagement at $1 \%$ significant level $(\mathrm{p}<0.01)$. Thus, null hypotheses(Ho3) is rejected.

$\mathrm{H}_{0}$ 4: There is no significant relationship between Perception on Performance Appraisal and Turnover Intention.

The correlation result indicates that there is a negative relationship between the Perception on Performance Appraisal and Turnover Intention at 5\% significant level ( $p>0.05)$. Thus, null hypotheses(Ho4) is accepted.

\section{Impact of Perception on Performance Appraisal over employees' Work Outcomes (Regression} Analysis)

For deeper understanding of the relationship between Perception on Performance Appraisal and employees' work outcomes, the regression analysis has been conducted. The summary of the analysis model of Perception on Performance Appraisal and its impact on employees' Work outcomes has been presented in table 7 and 8 . Model 1 provides the summary of relationship that exists in between Perception on Performance Appraisal and Work Performance. A variation of 42.3 percent in Work Performance is explained by Perception on Performance Appraisal $(\mathrm{t}=4.962, \mathrm{p}<0.01)$. Model 2 provides the summary of relationship that exists in between Perception on Performance Appraisal and Affective Commitment $(\mathrm{t}=6.013, \mathrm{p}<0.01)$. A variation of 63.9 percent in Affective Commitment is explained by Perception on Performance Appraisal. Model 3 provides the summary of relationship that exists in between Perception on Performance Appraisal and Employee Engagement. A variation of 60.6 percent in Employee Engagement is explained by Perception on Performance Appraisal $(\mathrm{t}=7.139, \mathrm{p}<0.01)$. Similarly, model 4 provides the summary of relationship that exists in between Perception on Performance Appraisal and Turnover Intention. A decreasing variation of 19.1 percent in Turnover Intention is explained by Perception on Performance Appraisal. However, the influence of the Perception on Performance Appraisal over Turnover Intention is not significant $(\mathrm{t}=(-) 1.170$, $\mathrm{p}>0.05)$.

Table 7: Model summary of the variable constructs

\begin{tabular}{|l|l|l|l|l|l|l|l|c|}
\hline Model & $\begin{array}{c}\text { Exogenous } \\
\text { Variable }\end{array}$ & $\begin{array}{c}\text { Endogenous } \\
\text { Variable }\end{array}$ & $\mathrm{R}$ & $\mathrm{R}^{2}$ & $\begin{array}{c}\text { Adjusted } \\
\mathrm{R}^{2}\end{array}$ & $\mathrm{SE}$ & $\mathrm{F}$ & $\mathrm{P}$ \\
\hline 1 & PPA & WP & 0.452 & 0.204 & 0.196 & 0.676 & 24.621 & 0.001 \\
\hline 2 & PPA & AC & 0.523 & 0.274 & 0.266 & 0.844 & 36.153 & 0.001 \\
\hline 3 & PPA & EE & 0.589 & 0.347 & 0.340 & 0.674 & 50.971 & 0.001 \\
\hline 4 & PPA & TI & 0.119 & 0.014 & 0.004 & 1.293 & 1.370 & 0.245 \\
\hline
\end{tabular}


Table 8: Unstandardized coefficient and $t$ statics of the variable constructs

\begin{tabular}{|l|l|l|l|l|l|l|c|}
\hline Model & $\begin{array}{c}\text { Exogenous } \\
\text { Variable }\end{array}$ & $\begin{array}{c}\text { Endogenous } \\
\text { Variable }\end{array}$ & $\begin{array}{c}\alpha \\
\text { (constant) }\end{array}$ & $\begin{array}{c}\beta \\
(\text { Un- } \\
\text { standardized) }\end{array}$ & SE & $\mathrm{t}$ & $\mathrm{p}$ \\
\hline 1 & PPA & WP & 2.761 & 0.423 & 0.085 & 4.962 & 0.001 \\
\hline 2 & PPA & AC & 1.215 & 0.639 & 0.106 & 6.013 & 0.001 \\
\hline 3 & PPA & EE & 1.615 & 0.606 & 0.085 & 7.139 & 0.001 \\
\hline 4 & PPA & TI & 4.783 & $(-) 0.191$ & 0.163 & -1.170 & 0.245 \\
\hline
\end{tabular}

\section{DISCUSSION}

The major objective of this research was to find out the relationship between perception on performance appraisal and its effects on employees' work outcomes. The research was conducted with the sample size of 98 employees of Nepalese service sector organizations. Results of the study indicate that there is a moderate perception on performance appraisal and employees' work outcomes in the Nepalese service organizations. The past research by Dechev (2010), has found the link between perceptions on performance appraisal. The key findings indicate that effective performance appraisal positively influences employees 'work performance, affective commitment, employee engagement' where else negatively influences the employees 'turnover intention'. The finding also highlights that employees must experience positive appraisal reactions in order for performance appraisal to positively influence employee work outcomes (Kuvaas, 2006; Murphy and Cleveland, 1995).

Furthermore, the results also indicate that there is a significant negative relationship between perception on Performance and Turnover Intention. The finding indicates that employees who perceive that they have been provided with unfair Performance Appraisal tend to have high level of turnover intention. The same result has been highlighted in Kuvaas (2006) and Vignaswaran (2008) that suggests that Performance Appraisal is more affective in influencing the behavioral intentions (Turnover Intention).

\section{CONCLUSION}

The primary objective of this study was to assess the influence of perception on performance appraisal on employee's work outcomes, because performance appraisal has been an issue of major concern with its long lasting impacts on the employees' work outcomes, in the form of work performance, affective commitment, employee engagement and turnover intention, which in turn, leads to the organizational performance. The study has been successful in accomplishing its research objectives and it makes contributions to the literature.

It can be concluded that there is a significant positive relationship of perception on Performance Appraisal and Work Performance, Affective Commitment and Employee Engagement. Likewise, there is a significant negative relationship of perception on Performance Appraisal and Turnover Intention. Furthermore, there is an impact of perception on Performance Appraisal on subsequent employees' work outcomes. If changes happen in Performance Appraisal then there will be significant impact on all the dependent variables i.e. Work Performance, Affective Commitment, Employee Engagement and Turnover Intention.

\section{THE WAY FORWARD}

Future research should attempt to investigate the effect of performance appraisal on other types of employee outcomes such as job satisfaction, job involvement and employee absenteeism. The suggestions for further researcher who want to conduct study in this very topic are summarized as follows:

- Performance appraisal may lead to better compensation and promotion. Therefore, future research could use both intrinsic and extrinsic motivation (promotion, rewards) as independent variables. 
- Future research could concentrate on conducting a similar study to explore the differences between performance appraisal satisfaction between the public and the private sectors in Nepal; to measure the differences in the level of impact performance appraisal has on employee outcomes within these two sectors.

- The study involved a quantitative research method. Future research could include qualitative research methods for analysis.

- This research is entirely made for the academic purpose. Thus, same sort of research can be done for the professional purpose.

(Acknowledgement: I would like to extent my thanks to Ramila Shrestha for helping me to collect a part of data for this research study.)

\section{References}

1. Ahmed, A., Hussain, I., Ahmed, S., \& Akbar, M. F. (2010). Performance appraisals impact on attitudinal outcomes and organisational performance. International Journal of Business and Management, 5(10), 62-68.

2. Allen, N. J., \& Meyer, J. P. (1990). The measurement and antecedents of affective, continuance and normative commitment to the organization. Journal of occupational and organizational psychology, 63(1), 1-18.

3. Arshad, M. A., Masood, M. T., \& Amin, G. (2013). Effects of performance appraisal politics on job satisfaction, turnover intention and loyalty to supervisor: study with reference to the telecom organizations of Pakistan. International Review of Management and Business Research, 2(3), 653.

4. Bandura, A. (1997). Self-efficacy: The exercise of control. Macmillan.Kanfer et al., 2005).

5. Barrick, M. R., \& Zimmerman, R. D. (2009). Hiring for retention and performance. Human Resource Management, 48(2), 183-206.Murphy, 2002).

6. Biswakarma, G. (2016). Performance appraisal and its effects on employees' attitude: an empirical support from Nepalese commercial banks. Journal of Management and Development Review. 6 (1), 6-22.

7. Dechev, Z. (2010). Effective Performance Appraisal: A Study into the Relation Between Employer Satisfaction And Optimizing Business Results. Erasmus University.

8. DeCotiis, T. A., \& Summers, T. P. (1987). A path analysis of a model of the antecedents and consequences of organizational commitment. Human relations, 40(7), 445-470.

9. Femi, A. F. (2013). Perception of performance appraisal and workers' performance in Wema Bank headquarters, Lagos. Global Journal of Arts, Humanities and Social Sciences, 1(4), 89101.

10. Gallato, C. G., Rashid, S., Suryasaputra, R., Warokka, A., Reamillo, K. A. G., \& bin Abdullah, H. H. (2012). Fostering niches among SMEs in Malaysia through organizational commitment, leadership, organizational culture and job satisfaction. Journal of Innovation Management in Small \& Medium Enterprises, 2012, 1.

11. Greenberg, J. (1986). Determinants of perceived fairness of performance evaluations. Journal of applied psychology, 71(2), 340.

12. Greenberg, J. (2004). Stress Fairness to Fare No Stress:: Managing Workplace Stress by Promoting Organizational Justice. Organizational Dynamics, 33(4), 352-365.

13. Hewitt, A. (2012). 2012 Trends in global employee engagement. Aon Corporation. Retrieved August, 11, 2013.

14. Hochschild, A. R. (1983). The managed heart. Berkeley.

15. Ilgen, D. R., Barnes-Farrell, J. L., \& McKellin, D. B. (1993). Performance appraisal process research in the 1980s: what has it contributed to appraisals in use?. Organizational Behavior and Human Decision Processes, 54(3), 321-368.

16. Kahn, W. A. (1990). Psychological conditions of personal engagement and disengagement at work. Academy of management journal, 33(4), 692-724. 
17. Khan, M. (2013). Role of performance appraisal system on employees motivation. IOSR Journal of Business and Management, 8(4), 65-83.

18. Klein, H. J., \& Snell, S. A. (1994). The impact of interview process and context on performance appraisal interview effectiveness. Journal of managerial issues, 160-175.

19. Kuvaas, B. (2006). Performance appraisal satisfaction and employee outcomes: mediating and moderating roles of work motivation. The International Journal of Human Resource Management, 17(3), 504-522.

20. Levy, P. E., \& Williams, J. R. (2004). The social context of performance appraisal: A review and framework for the future. Journal of management,30(6), 881-905.

21. Maund, L. (2001). Introduction to human resource management: theory and practice. Palgrave.

22. Meyer, J. P., \& Allen, N. J. (1991). A three-component conceptualization of organizational commitment. Human resource management review, 1(1), 61-89

23. Morrow, P. C. (1983). Concept redundancy in organizational research: The case of work commitment. Academy of management Review, 8(3), 486-500.

24. Morrow, P. C. (2011). Managing organizational commitment: Insights from longitudinal research. Journal of Vocational Behavior, 79(1), 18-35.

25. Mowday, R. T., Porter, L. W., \& Steers, R. M. (1982). Employee-organization linkage. The psychology of commitment absenteeism, and turn over_Academic Press Inc. London.

26. Murphy, K. R., \& Cleveland, J. (1995). Understanding performance appraisal: Social, organizational, and goal-based perspectives. Sage.

27. Nurse, L. (2005). Performance appraisal, employee development and organizational justice: exploring the linkages. The International Journal of Human Resource Management, 16(7), 1176-1194.

28. Pandey, K. (1988). A Gateway for Nepalese Human Resource for Global Competitive Market. Internal Human Resource Management, 2 (1), 196-204.

29. Price, J. L. (1977). The study of turnover. Iowa State Press.

30. Rao, S. (2005). Human Resource Management: Text and Cases (2nd ed.). New Delhi: Excel Books.

31. Schaufeli, W. (2002). The measurement of engagement and burnout: A two sample confirmatory factor analytic approach. Journal of Happiness Studies. Journal of Happiness Studies, 71-92.

32. Selvarajan, R., \& Cloninger, P. A. (2009). The influence of job performance outcomes on ethical assessments. Personnel Review, 38(4), 398-412.

33. Suliman, A. M. (2001). Work performance: is it one thing or many things? The multidimensionality of performance in a Middle Eastern context.International Journal of Human Resource Management, 12(6), 1049-1061.

34. Vandenberg, R. J., \& Nelson, J. B. (1999). Disaggregating the Motives Underlying Turnover Intentions: When Do Intentions Predict Turnover Behavior?. Human Relations, 52(10), 13131336.

35. Vignaswaran, R. (2005). The relationship between Performance Appraisal Satisfaction and Employee Outcomes: A study conducted in Peninsular Malaysia. (Unpublished Thesis) University of Malaya.

36. Vignaswaran, R. (2008). The relationship between performance appraisal satisfaction and employee outcomes: a study conducted in Peninsular Malaysia. Master. Malaysia: University of Malaya. 